\title{
Urban flood susceptibility evaluation and prediction during 2010-2030 in the southern watersheds of Mashhad city, Iran
}

\author{
Elham Heidari ${ }^{1 *}$, Amir Mahmoudzadeh ${ }^{2}$ and Mohammad Reza Mansouri Daneshvar ${ }^{3}$ (B)
}

\begin{abstract}
Background: Urban flood susceptibility evaluation (FSE) can utilize empirical and rational procedures to focus on the urban flood evaluation using physical coefficients and land-use change ratios. The main aim of the present paper was to evaluate a flood susceptibility model in the southern watersheds of Mashhad city, in Iran, for 2010, 2020, and 2030. The construction of the model depended on the utilization of some global datasets to estimate the runoff coefficients of the watersheds, peak flood discharges, and flood susceptibility evaluations.
\end{abstract}

Results and conclusions: Based on the climatic precipitation and urban sprawl variation, our results revealed the mean values of the runoff coefficient (Cr) from 0.50 (2010) to 0.65 (2030), where the highest values of $\mathrm{Cr}(>0.70)$ belonged to the watersheds with real estate cover, soil unit of the Mollisols, and the slope ranges over $5-15 \%$. The averagely cumulative flood discharges were estimated from $2.04 \mathrm{~m}^{3} / \mathrm{s}(2010)$ to $5.76 \mathrm{~m}^{3} / \mathrm{s}(2030)$, revealing an increase of the flood susceptibility equal 3.2 times with at least requirement of an outlet cross-section by $>46 \mathrm{~m}^{2}$ in 2030 . The ROC curves for the model validity explained AUC values averagely over 0.8 , exposing the very good performance of the model and excellent sensitivity.

Keywords: Urban sprawl, Flood susceptibility evaluation (FSE), Geographical information system (GIS), Global datasets, Mashhad city

\section{Introduction}

Recent scientific publications support the fact that the occurrences of climate-related disasters (e.g., flash floods and severe storms) have significantly increased under the abrupt changes through the hydro-meteorological conditions (Huang et al. 2017; Ahmadi and Moradkhani 2019; Mihu-Pintilie et al. 2019). On the other side, many researchers have reported that increasing urbanization can induce higher flash flood occurrences in urban areas (Ahmad et al. 2017; Scionti et al. 2018; Shah et al. 2020).

\footnotetext{
*Correspondence: elham.heidari.inquiry@gmail.com

1 Department of Geography and Urban Planning, Research Institute of Shakhes Pajouh, Isfahan, Iran

Full list of author information is available at the end of the article
}

According to the literature review, the flood events in urban areas notably have increased trends influenced by climate change and urban sprawl expansion (e.g., Ntelekos et al. 2010; Huong and Pathirana 2013; Li et al. 2013; Zhao et al. 2019). An important point is a balance between urban sprawl development and climate change effects through the future flash flood susceptibility (Dawson et al. 2011). Urban growth can be responsible for over $50 \%$ of the increase in flood risk, and urban areas face global challenges of flood susceptibility due to climate change and the development of residential areas and urban sprawl (Berndtsson et al. 2019).

In this regard, urbanization impacts on runoff measures and flood damages are important fields of research (Isidoro et al. 2012), especially in the non-western 
developing countries. For instance, the study of Abass et al. (2020) explained a direct relationship between urban sprawl and flood occurrence using geospatial techniques and field observations in Ghana. Similarly, the hydraulic modeling of urban floods by Devi et al. (2019) indicated the average increase in inundation extent considering the urban sprawl and extreme rainfall event in India.

Several models have been used to approximate the urban flood modeling on several local and national scales regarding the previous works. For instance, Tierolf et al. (2021) have used a flood assessment based on land-use change characteristics in the present and future periods, and they revealed an overall increase in urban flood risk in Southeast Asian countries. Using a hydrological model system (HMS), Feng et al. (2021) reported that areas influenced by a flash flood and floodplain increase due to the urbanization process in Canada. Also, in other researches, Dastorani et al. (2010) and Hoseini et al. (2017) have analyzed the flood-discharge using watershed modeling systems (WMS) and revealed suitable results adopting with local empirical findings. Furthermore, some studies using land-use classification and hydrologic models (e.g., Kulkarni et al. 2014; Zope et al. 2016; Wagner et al. 2016) revealed the increased runoff and flood susceptibility for Indian urban areas in the future.

It is not easy to quantify the urbanization impact on flooding since different urbanization scenarios result in different outcomes (Du et al. 2012; Fletcher et al. 2013). Overall, flood susceptibility increases significantly by transitioning from natural areas to urban sprawl fields (Prosdocimi et al. 2015; Miller and Hutchins 2017). In this regard, more statistical studies should be carried out to show the long-term quantitative effects of urban development in the flood susceptibility evaluation (Berndtsson et al. 2019). Urban flood susceptibility evaluation (FSE) and management is a proper way to mitigate the urban human losses and economic damages (Tingsanchali 2012), which utilizes the empirical and rational procedures to focus on the urban flood evaluation using physical coefficients and land-use change ratios (Su 2017).

Iran is highly disaster-prone, suffering from droughts, floods, earthquakes, landslides, and anthropogenic and technological disasters. In the semi-arid regions of Iran, flash floods are categorized as a dangerous type of hydroclimatic hazard. For example, in March 2019, Iran experienced several major waves of storms and heavy rainfall within some weeks, demonstrating anomalous events in the past 100 years. According to government official reports, the flash floods have burst about 140 watershed down-streams and inundated about 200 urban areas (UNCTI 2019). Accordingly, the severe flooding of 2019 in Iran was a great momentum for the urban decision-makers and dwellers to consider the forthcoming urban flood hazards in the pre-urban and urban watersheds.

Now, the main aim of the present paper is to evaluate a flood susceptibility model in the southern watersheds of Mashhad city, in Iran, during three temporal windows of 2010, 2020, and 2030. The construction of the model depends on the utilization of some global remotely sensed (RS) and reanalyzed datasets through geographical information system (GIS) to evaluate spatial and temporal levels of runoff variations, peak flood discharges, and flood hazard susceptibilities toward the urban sprawl and land-cover changes. The integration of both GIS and RS presents an exceptional technique in monitoring and predicting urban growth and urban floods (e.g., Park et al. 2011; Al-Ghamdi et al. 2012).

\section{Study area}

The area under investigation includes about 22 pre-urban and urban watersheds in the southern Mashhad city, Iran, which located between $36^{\circ} 15^{\prime}$ and $36^{\circ} 20^{\prime} \mathrm{N}$ latitudes and $59^{\circ} 26^{\prime}-59^{\circ} 34^{\prime} \mathrm{E}$ longitudes (Fig. 1). Based on the urbanized elements, the study area is located between two main orchards of the Mashhad, namely Vakil-Abad and Malek-Abad gardens. According to the municipal administrative boundaries in 2020, the study area with a population rate of 340,000 inhabitants as $10.8 \%$ from the total Mashhad city $(3,128,000)$ and a surface area of $43.3 \mathrm{~km}^{2}$ as $12.7 \%$ from the entire city $\left(340 \mathrm{~km}^{2}\right)$, belongs to the Region 9. This region is located over the southern mountains of the Mashhad, including the natural relief and ecological and recreational landscapes. The study area has a semi-arid climate with a mean annual temperature of $14{ }^{\circ} \mathrm{C}$ and annual precipitation of $260 \mathrm{~mm}$ based on a long-term database (Yazd et al. 2019).

Some of the study watersheds (e.g., watersheds W11, $\mathrm{W} 12$, W13, and W14) dominantly are the natural upstream areas, which urban residential sprawls and real estates have not degraded. However, the downstream parts of the study area located on the watersheds W17, W21, and W22, wholly comprise the urban real estate. The focal outlets of all watersheds in the W10 are flowed across the Ferdowsi University zone and are effluent in the main channel into the Malek-Abad Garden, draining stream flows to the Kashafrud River in the northern part of the city.

During the several stages of urban sprawl development, the natural parts of the study area have suffered from urban sprawl growth, especially along the several main roads such as Piruzi, Fakuri, and Namaz highways. In recent years, the construction of the southern highway has destroyed the natural patterns of the study area, inducing the sprawl diffusion into the natural upstream 


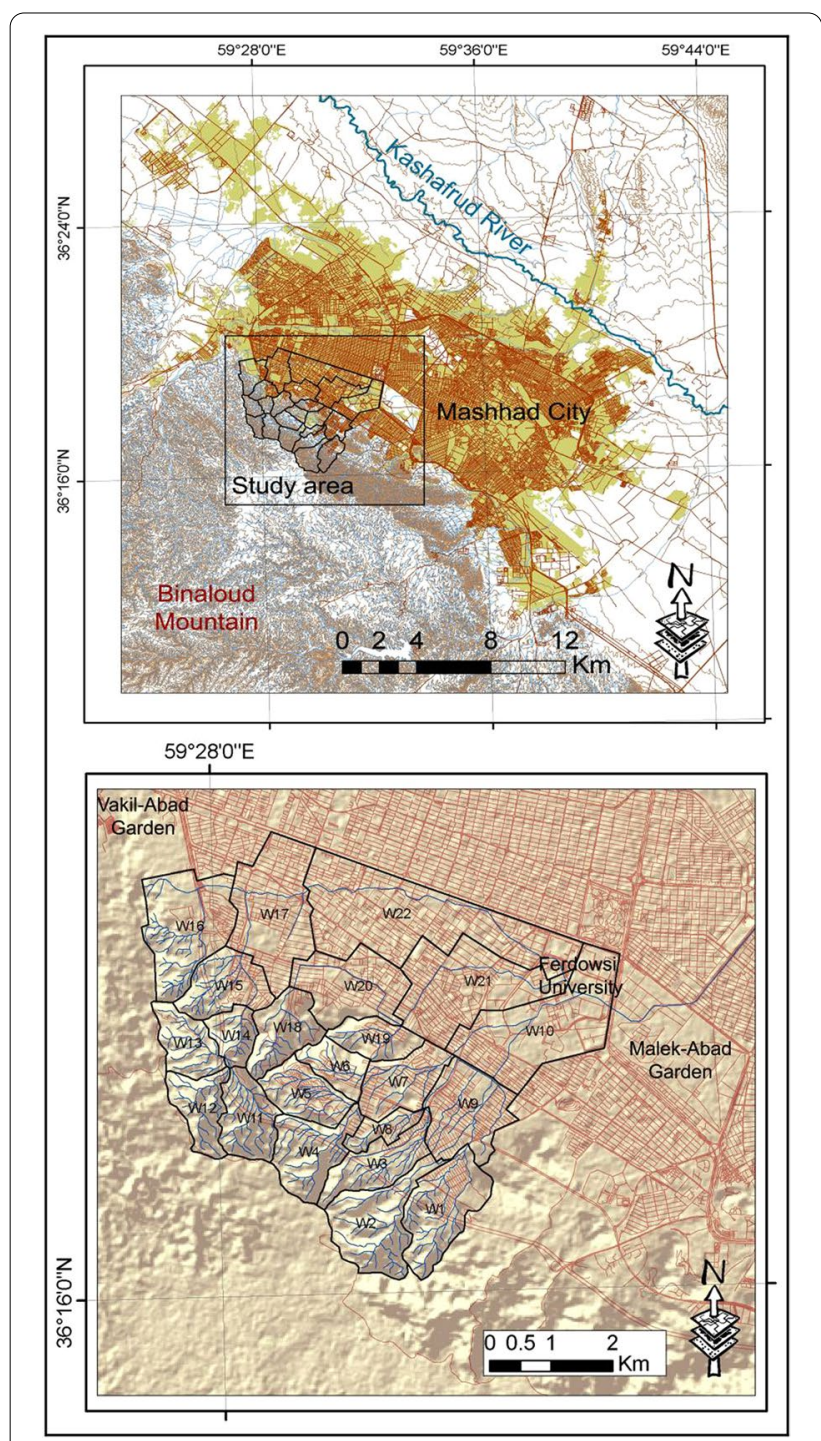

Fig. 1 Geographical location of the study area

watersheds and variation of the magnitude and frequency of the flooding occurrences. Hence, it may be anticipated that the expansion of urban real estate in the study area will influence the risk of future flooding events within the next decade.

\section{Data and methods}

\section{Data preparation}

Data preparation of this study follows the research model of the present study (Fig. 2) and needs to consider at least five global datasets. In this regard, the remotely sensed and reanalyzed data were gathered from spatial grid pixels or time series, focusing on the study area's geographical coordination (i.e., $36^{\circ} \mathrm{N}$ and $59^{\circ} \mathrm{E}$ ).
The procedure for detecting and identifying the datasets presented here is based on Rabbani et al. (2021). Land characteristics of the watersheds such as area, length, height, and slope were obtained from georeferenced tagged image files of the global digital elevation model derived (DEM) via https://lpdaac.usgs.gov/produ cts/astgtmv003 (from ASTER images version 003, with a horizontal resolution of $30 \mathrm{~m}$, released from 2013). The soil units of the study area were extracted from the global soil-grid dataset (with a pixel resolution of $250 \mathrm{~m}$, released from 2014) via https://soilgrids.org, exposing the soil properties and classes (Hengl et al. 2014, 2017). Land-use types and the land-cover dataset were considered from the global land-use/ land-cover (LULC) database via https://pdaac.usgs.gov/products/mcd12q1v006 (from MODIS images with a pixel resolution of $500 \mathrm{~m}$, version 006, yearly) retrieved from satellite products in 2010 (Li et al. 2017).

The spatial expansion of the urban sprawl was estimated in the past (2010), present (2020), and the probable future (2030) based on the global dataset of human builtup and settlement extent (HBASE) via https://sedac. ciesin.columbia.edu/data/set/ulandsat-hbase-v1/datadownload, retrieved from Landsat imageries (available at 30-250 m resolution, version 001 based on the imageries in 2010) (Wang et al. 2017). Ultimately, the time-series of daily-precipitation rate (data with 0.1-degree resolution, from 1990 to 2021, FLDAS_NOAH01_C_GL_MA_v001) data was collected from the fourth version of the geospatial interactive online visualization and analysis infrastructure (GIOVANNI) program via https://giovanni. gsfc.nasa.gov/giovanni, maintained at NASA Goddard services center.

\section{Research model}

The FSE model, presented in this research (Fig. 2), includes some steps. First, we acquired several reanalyzed data (e.g., from DEM, soil grids, LULC, HBASE, and Giovanni) for producing the GIS-based spatial analysis or statistical time-series within 2010-2030 concerning the land and climatic characteristics (e.g., elevation, slope, soil units, land covers, urban sprawl, and precipitation rates). Second, the quantitative procedures were assumed to estimate the key hydrological factors of watersheds such as runoff coefficients $(\mathrm{Cr})$, precipitation intensities $(\mathrm{Pi})$, peak flood discharges $(\mathrm{Qp})$, concentration times $(\mathrm{Tc})$, and outlet cross-sections $(\mathrm{Sc})$ as are described in following equations.

The runoff and flood models, such as rational methods and empirical equations defined by Thompson 2006, Devi et al. (2019), and Cheah et al. (2019), could aid in the estimation of the number of precipitation rates, land characteristics, and some various physical 


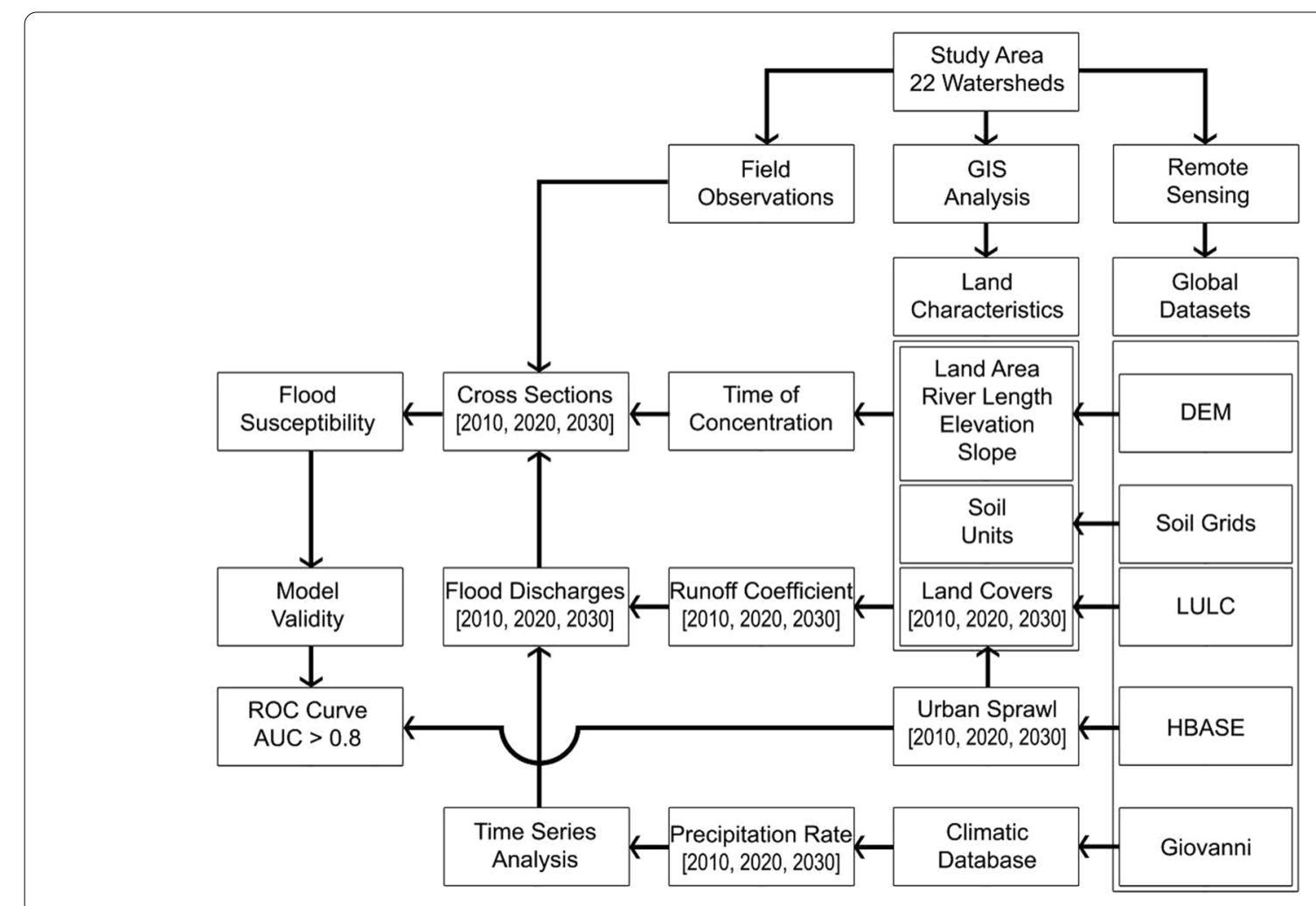

Fig. 2 Research model

parameters of the watersheds. Hence, the runoff coefficient $(\mathrm{Cr})$ is the ratio that depends on factors such as the intensity of soil units, the types of land-use/landcover, precipitation rates, and slope ranges (Mousavi et al. 2019). According to Table 1, the runoff coefficient of different watersheds can be determined by overlapping the aforementioned factors (e.g., Thompson 2006, Mousavi et al. 2019).

Accurate determination of the peak flood discharge in each watershed has the main role in managing water resources (Bhadra et al. 2008; Hoseini et al. 2017). According to Parak and Pegram (2006), the peak flood discharge due to an anomalous rainfall event on a watershed can be determined from the rational formula as expressed below equation:

$$
\mathrm{Qp}=\mathrm{Cr} \times \mathrm{Pi} \times A \times 3.6
$$

where Qp is the flood peak discharge in cubic meters per second $\left(\mathrm{m}^{3} / \mathrm{s}\right), \mathrm{Cr}$ is the runoff coefficient (unitless), $\mathrm{Pi}$ is the maximum precipitation intensity in millimeters per hour $(\mathrm{mm} / \mathrm{h})$ that is determined based on the time-series linear trend, and $\mathrm{A}$ is the watershed area in squared kilometers $\left(\mathrm{km}^{2}\right)$.

The time of concentration (Tc) for watershed flow is computed using Kirpich (1940) formula assigned by Thompson (2006), which has been calibrated using the

Table 1 Determination of the runoff coefficients $(\mathrm{Cr})$ in the watersheds of the study area based on the land covers, soil units and slope ranges (after Mousavi et al. 2019)

\begin{tabular}{|c|c|c|c|c|c|c|}
\hline \multirow[t]{3}{*}{ Soil units } & \multicolumn{6}{|l|}{ Land covers } \\
\hline & \multicolumn{3}{|c|}{ Rangeland (natural area) } & \multicolumn{3}{|c|}{ Real estate (urban sprawl) } \\
\hline & Slope $<5 \%$ & $5-15 \%$ & $>15 \%$ & Slope $<5 \%$ & $5-15 \%$ & $>15 \%$ \\
\hline Vertisols & 0.15 & 0.25 & 0.35 & 0.60 & 0.65 & 0.70 \\
\hline Entisols & 0.25 & 0.35 & 0.45 & 0.64 & 0.68 & 0.72 \\
\hline Mollisols & 0.30 & 0.40 & 0.50 & 0.66 & 0.70 & 0.75 \\
\hline
\end{tabular}


metric units following the lead of Petras and Du Plessis (1987) as below equation (Parak and Pegram 2006):

$$
T c=0.0633 \times\left(\frac{L^{2}}{S}\right)^{0.385}
$$

where Tc is the time of concentration for the watershed in the hour (h), $\mathrm{L}$ is the length of the longest watercourse $(\mathrm{km})$, and $\mathrm{S}$ is the slope of the longest watercourse $(\mathrm{km} /$ $\mathrm{km})$.

Furthermore, we can use an empirical equation to estimate the engineering dimensions of watershed outlets, floodways, and cross-sectional designs. On this basis and owing to the main factors of time of concentration $(\mathrm{Tc})$, peak flood discharges $(\mathrm{Qp})$, and the length of watersheds (L), the outlet cross-section (Sc) of each watershed is estimated to facilitate the hydraulic design and control using below equation:

$$
S c=Q p \times \frac{T c}{L}
$$

where Sc is the outlet cross-section $\left(\mathrm{m}^{2}\right)$, Qp is the flood peak discharge $\left(\mathrm{m}^{3} / \mathrm{s}\right)$, Tc is the time of concentration for the watershed (s), and $\mathrm{L}$ is the length of the longest watercourse $(\mathrm{m})$. In this step, the field observations were carried out in the outlet points of the watersheds to control the estimated results compared with the quo status (2020). Third, the flood susceptibility evaluation of the watersheds was approximated as the final output of the FSE model. In this regard, FSE of the watersheds within three periods of 2010, 2020, and 2030 were defined as the cumulative flood discharges of each watershed after the concentration times considering the upstream watershed discharges and outlet cross-sections. Ultimately, the model validity was computed based on the receiver operating characteristic $(\mathrm{ROC})$ procedure.

The ROC curve, a widely used informative area under the curve (AUC), was plotted to validate the flood susceptibility model in the present study regarding the urban sprawl effects. AUC ranges from 0.5 to 1 , where the AUC values above 0.8 represent the very good performance of the model and excellent sensitivity (Yesilnacar and Topal 2005). The overall performance indicator of a model is drawn by plotting false positive (FP) rate or 1-specificity on the $\mathrm{x}$-axis against true positive (TP) rate or sensitivity on the $y$-axis in a ROC curve (Liuzzo et al. 2019; Pirnia et al. 2019). The methodological details of the ROC metrics have been well described by Rahmati et al. (2019) and Rahman et al. (2021).

\section{Results and discussion}

\section{Estimation runoff coefficients}

The runoff coefficient is one of the important parameters considered in surface runoff and flood discharge estimation methods in various watershed management and flood control projects (Zeinali et al. 2019). Theoretically, the runoff coefficient is a fraction of rainfall volume retained by the land, soil, and vegetation characteristics, i.e., it relates to the transformation of the total rainfall in net rainfall influenced by infiltration, canopy interception, and surface detention (Del Giudice et al. 2014). In the rational/empirical method, $\mathrm{Cr}$ values can be calculated based on the land use/land cover classified map in addition to the slope layer and the hydrological group of the soil units (Mousavi et al. 2019). According to Table 1, we need to verify some physical factor layers of each watershed in the study area to determine the $\mathrm{Cr}$ values because the runoff coefficient of different watersheds is typically determined by overlapping some land cover and slope layers (Thompson 2006; Suharyanto et al. 2021). For instance, the $\mathrm{Cr}$ values for a region with a cover of rangeland, slope range of below 5\%, and soil unit of Entisols can be calculated as 0.25 . Accordingly, the dominant situation of land cover, slope range, and soil unit were extracted for each watershed in GIS using the Zonal Statistics extension to estimate a principal $\mathrm{Cr}$ value for each watershed. It should be noted that the small urban and pre-urban watersheds are often represented in single land use and soil unit classes in flood risk assessments (Tierolf et al., 2021). Hence, the $\mathrm{Cr}$ values can be fixed in the limited values (0-1) drawn in a table (Baiamonte 2020).

\section{Analyzing DEM and soil data}

For this purpose, the elevation and slope maps, derived from DEM data, in addition to soil units map, acquired from the global soil grid dataset, were produced in GIS (Fig. 3). The dominant characteristics of each watershed were extracted using the zonal statistics in GIS in Table 2.

On this basis, the surface areas of the study watersheds vary from 0.45 to $4.43 \mathrm{~km}^{2}$. Total 22 watersheds are located in the altitude range of $1020-1520 \mathrm{~m}$ above sea level. The variation of averagely length and $\Delta$ height of the watersheds obtained equal $1.1-4.7 \mathrm{~km}$ and $50-400 \mathrm{~m}$, respectively. About 16 watersheds (55\% of the total study area) have critical slope ranges over $15 \%$, and dominant soil units in 14 cases out of 22 watersheds ( $48 \%$ of the total study area) are observed as Mollisols. The soil unit of the Mollisols could be considered as the most intensive soil loss-prone zone in the study area around Mashhad 


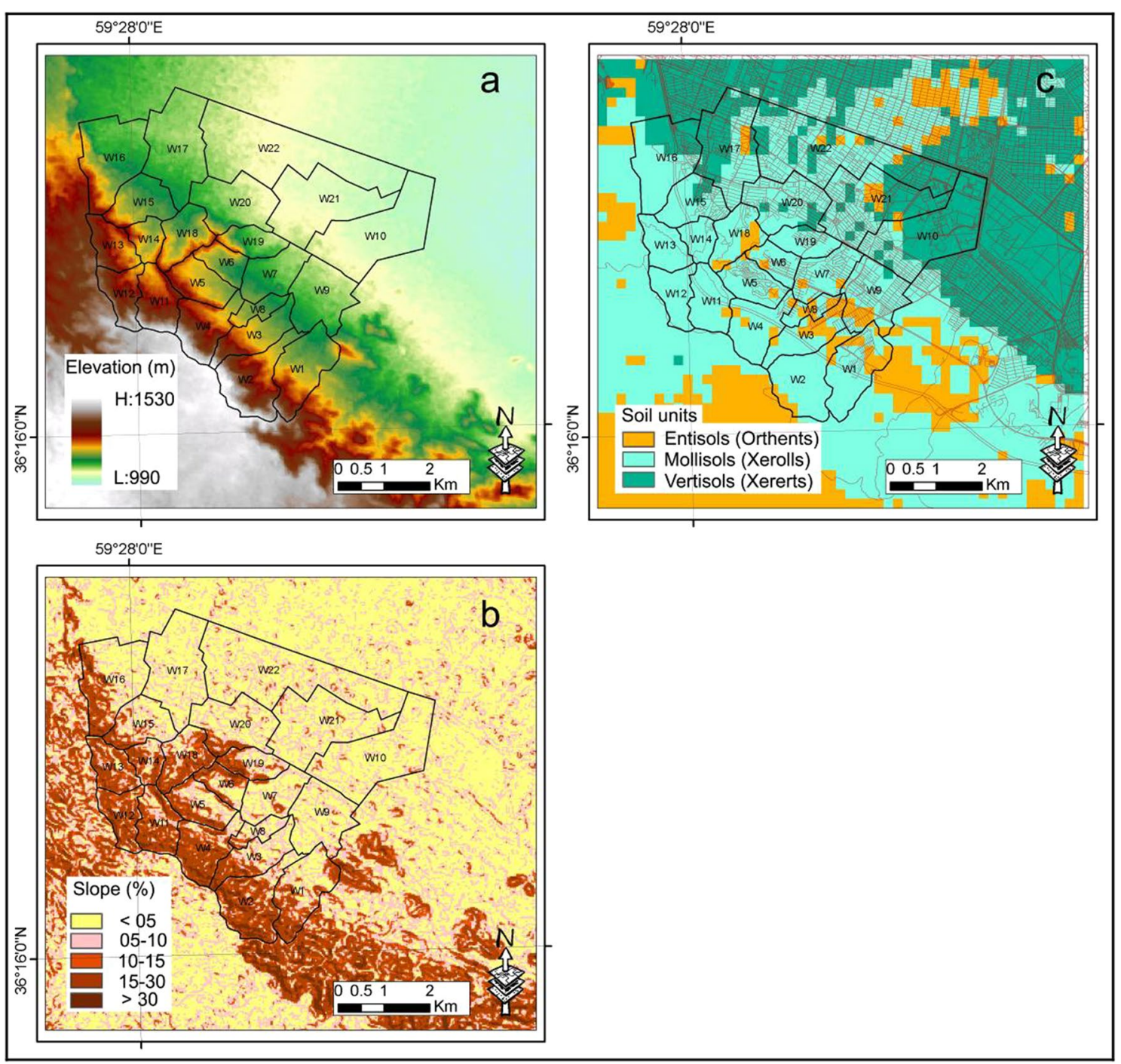

Fig. 3 Land characteristics of the study area including $\mathbf{a}$ elevation, $\mathbf{b}$ slope, and $\mathbf{c}$ soil units

city and due to its relation with the barren land and brown-fields (Ebrahimi et al. 2021).

\section{Attributing land-cover data}

According to the global land-use/land-cover (LULC) as well as HBASE dataset, derived from satellite imageries, the main types of land-cover of the study area in 2010 dominantly are categorized as rangeland area $(60 \%)$ and residential real estate (40\%). The percentage of land-cover types in the quo status (2020) is changed as $45 \%$ and $55 \%$ for rangeland and real estate areas, respectively. Moreover, the contribution of the rangeland and the sprawl expansion of real estate area to the land-cover types can be anticipated equal to $20 \%$ and $85 \%$, respectively, in 2030 (Fig. 4). A dominant trend of sprawl growth in the study period (2010-2030) depends on the leapfrog expansion of the new settlements around the main roads and highways. The pattern of the new settlement in this part of the Mashhad city is contributed to suburb real estates and occupied brown-fields, which absorbed increasing urban sprawl (Yazd et al. 2019). The zonal statistics of land covers are presented for each watershed in Table 3. The urban sprawl effect and real estate cover have influenced the study area by 7 watersheds ( $45 \%$ of total area) and 12 watersheds (65\% of total area) from 2010 to 2020 , and it is predicted for 18 watersheds (> $85 \%$ of total area) up to 2030.

In Fig. 5, the satellite imageries (Google Earth) and general perspectives for a sample of the sprawl expansion are shown for two time-windows of 2010 (past) and 
Table 2 Main physical characteristics of the watersheds

\begin{tabular}{|c|c|c|c|c|c|c|c|}
\hline Watershed & Area $\left(\mathrm{km}^{2}\right)$ & $\begin{array}{l}\text { River length } \\
(\mathrm{km})\end{array}$ & $\Delta$ height (km) & $\begin{array}{l}\text { Max. altitude } \\
\text { (m) }\end{array}$ & Min. altitude (m) & Soil unit & Slope (\%) \\
\hline W1 & 1.72 & 2.40 & 0.32 & 1440 & 1120 & Mollisols & $>15$ \\
\hline W2 & 1.77 & 2.60 & 0.38 & 1520 & 1140 & Mollisols & $>15$ \\
\hline W3 & 1.14 & 2.50 & 0.40 & 1520 & 1120 & Entisols & $>15$ \\
\hline W4 & 1.33 & 1.90 & 0.36 & 1520 & 1160 & Mollisols & $>15$ \\
\hline W5 & 1.01 & 1.60 & 0.19 & 1350 & 1160 & Mollisols & $>15$ \\
\hline W6 & 0.67 & 1.10 & 0.14 & 1270 & 1130 & Mollisols & $>15$ \\
\hline W7 & 1.16 & 1.50 & 0.10 & 1180 & 1080 & Mollisols & $<5$ \\
\hline W8 & 0.45 & 1.40 & 0.13 & 1250 & 1120 & Entisols & $5-15$ \\
\hline W9 & 1.72 & 1.50 & 0.08 & 1150 & 1070 & Mollisols & $<5$ \\
\hline W10 & 3.11 & 2.90 & 0.06 & 1080 & 1020 & Vertisols & $<5$ \\
\hline W11 & 1.11 & 1.90 & 0.30 & 1500 & 1200 & Mollisols & $>15$ \\
\hline W12 & 0.92 & 1.90 & 0.27 & 1470 & 1200 & Mollisols & $>15$ \\
\hline W13 & 0.91 & 1.40 & 0.20 & 1400 & 1200 & Mollisols & $>15$ \\
\hline W14 & 0.59 & 1.10 & 0.14 & 1300 & 1160 & Mollisols & $>15$ \\
\hline W15 & 1.20 & 1.30 & 0.20 & 1330 & 1130 & Mollisols & $5-15$ \\
\hline W16 & 2.25 & 2.50 & 0.25 & 1350 & 1100 & Vertisols & $5-15$ \\
\hline W17 & 2.50 & 1.80 & 0.05 & 1140 & 1090 & Vertisols & $<5$ \\
\hline W18 & 1.09 & 1.70 & 0.17 & 1300 & 1130 & Entisols & $>15$ \\
\hline W19 & 0.76 & 1.20 & 0.20 & 1280 & 1080 & Mollisols & $5-15$ \\
\hline W20 & 1.77 & 2.50 & 0.18 & 1260 & 1080 & Mollisols & $5-15$ \\
\hline W21 & 2.74 & 3.20 & 0.05 & 1080 & 1030 & Vertisols & $<5$ \\
\hline W22 & 4.43 & 4.70 & 0.06 & 1090 & 1030 & Vertisols & $<5$ \\
\hline
\end{tabular}

2020 (present). In this Figure, we can observe the creeper expansion of urban real estate around the Namaz highway (in the southern part of two isolated hills). This fact reveals that the construction of any main roads (such as the Southern highway) can trigger the sprawl expansion and impervious surfaces over the watersheds during the next time-periods.

\section{Estimating runoff coefficients $(\mathrm{Cr})$}

The $\mathrm{Cr}$ values in each watershed were calculated in Table 3 using the overlapping some data layers (i.e., land cover map, slope range, and soil units) and considering Table 1. In this regard, the mean values of $\mathrm{Cr}$ are changed from 0.50 (in 2010) to 0.65 (in 2030). The highest values of $\mathrm{Cr}(>0.70)$ belong to the watersheds with real estate cover, soil unit of Mollisols, and the slope ranges over $5-15 \%$, which will be predicted in 2030 for 7 watersheds (W1, W3, W5, W6, W13, W14, and W18) in the upstream location of the study area (Fig. 6). The highest values of $\mathrm{Cr}(>0.70)$ in the present time are estimated only in a watershed (W6) in the central part of the study area. Several scholars have demonstrated that the urbanized watersheds with much more runoff coefficient $(\mathrm{Cr})$ will produce much more flood discharge and susceptibility (Hung et al. 2018; Zeinali et al. 2019). Hence, predicting watersheds with high $\mathrm{Cr}$ values should make the urban decision-makers aware of the critical effects of sprawl expansion on the increasing flood hazards in the pre-urban areas. In the next section, we will estimate the accurate quantity of flood discharges in the study area.

\section{Estimation peak flood discharges}

Equation 1 revealed that in addition to runoff coefficients $(\mathrm{Cr})$, we need to determine the precipitation rate to estimate each watershed's peak flood discharges (Qp).

\section{Analyzing precipitation data}

Precipitation rates describe the water supply to a watershed, a portion of which reaches the watershed outlet as surface runoff. The amount and duration of the precipitation rates are the essential characteristics of a storm for hydrologic analysis and can be combined to describe the intensity and frequency of the precipitation (Hayes and Young 2006). During the flash flood events in 2019, as anomalous events within the last 100 years (UNCTI 2019), some western and northeastern Iran watersheds have experienced the maximum daily-precipitation rates over 120-160 mm (Mahmoudzadeh and Daneshvar 2019). 


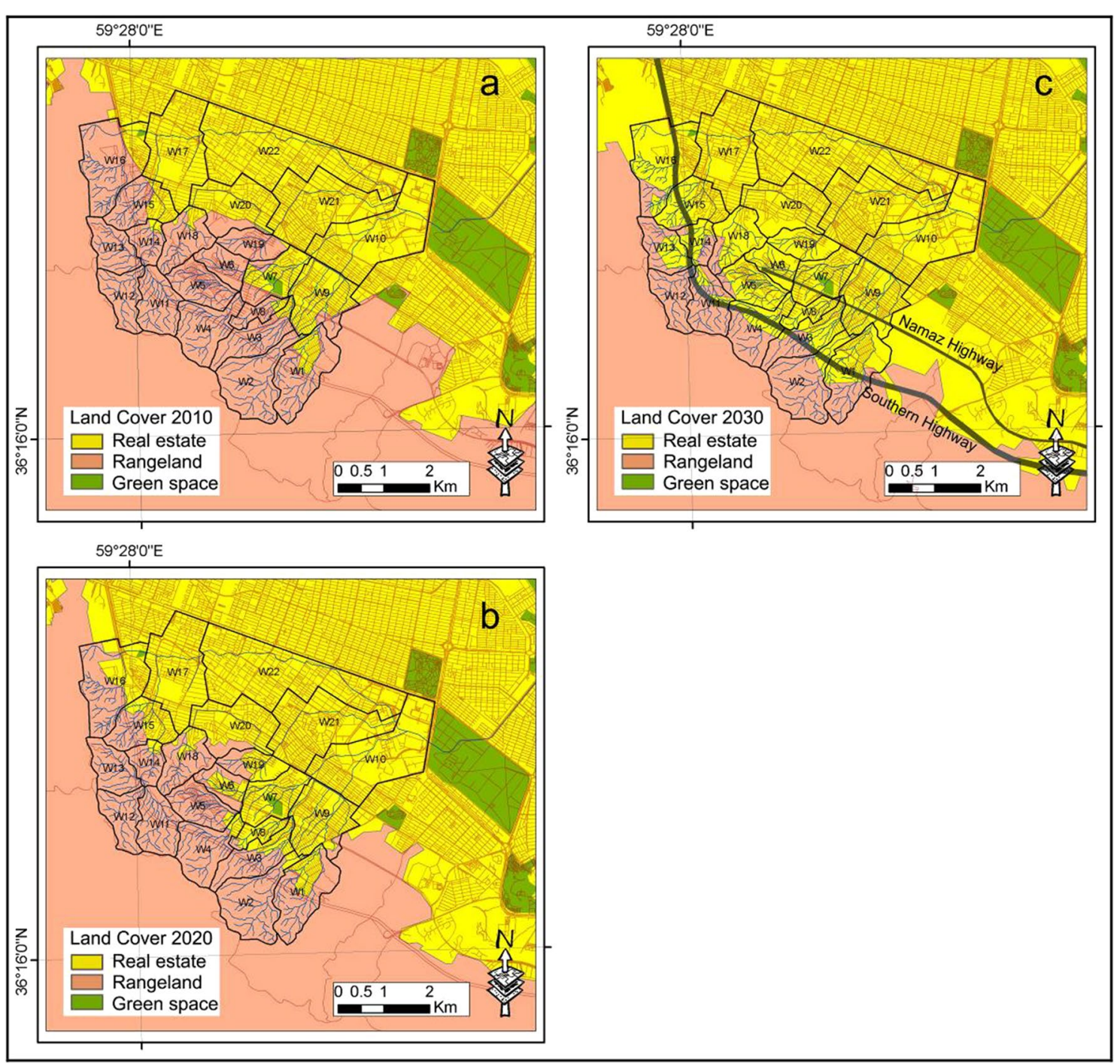

Fig. 4 Land cover properties of the study area for three time windows of a 2010, b 2020, and c 2030

In this study, we assumed the mean daily-precipitation rates between 2001 and 2020 for the Mashhad city shown in Fig. 7. Among these data, the maximum values of precipitation rate per hour were analyzed in Fig. 8 to reveal the linear trend equation as below (same as the method used by Shanableh et al. 2018), demonstrating the increasing trend of anomalous daily-precipitation intensity (Pi) in the study area from 2001 to 2020 :

$$
P i=1.24 \times(\text { Year }-2001)+9.74
$$

According to the precipitation data from 2001 to 2020 and its linear trend equation, the regression coefficient and coefficient of determination (R-squared) were obtained as 0.55 and 0.30 , representing $30 \%$ of the dependent variable $(\mathrm{Pi})$ can be predicted by the independent variable (Year). Due to anomalous precipitation rates in recent years (2018-2020), the goodness of fit in this equation is not maxima but is good enough to determine the future chaotic precipitation events in the study area.

The estimated maximum values of daily precipitation rate for the study area can be assumed as 20,34 , and $47 \mathrm{~mm} / \mathrm{h}$ for time windows of 2010, 2020, and 2030, respectively. These estimations revealed an increasing trend for precipitation extremes ranging from 1.7 to 2.4 times in 2020 and 2030 regarding 2010. Although this range of variations in precipitation ranges depends on the peak of rainfall anomalies in the given study area and may not represent the actual climate change 
Table 3 Land-use/land-cover expansions and the runoff coefficients (unitless) in the watersheds within three periods of 2010, 2020, and 2030

\begin{tabular}{|c|c|c|c|c|c|c|}
\hline Watershed & 2010 land covers & 2020 land covers & 2030 land covers & $\begin{array}{l}2010 \text { runoff } \\
\text { coefficient }\end{array}$ & $\begin{array}{l}2020 \text { runoff } \\
\text { coefficient }\end{array}$ & $\begin{array}{l}2030 \text { runoff } \\
\text { coefficient }\end{array}$ \\
\hline W1 & Rangeland & Rangeland & Real estate & 0.50 & 0.50 & 0.75 \\
\hline W2 & Rangeland & Rangeland & Rangeland & 0.50 & 0.50 & 0.50 \\
\hline W3 & Rangeland & Rangeland & Real estate & 0.45 & 0.45 & 0.72 \\
\hline W4 & Rangeland & Rangeland & Rangeland & 0.50 & 0.50 & 0.50 \\
\hline W5 & Rangeland & Rangeland & Real estate & 0.50 & 0.50 & 0.75 \\
\hline W6 & Rangeland & Real estate & Real estate & 0.50 & 0.75 & 0.75 \\
\hline W7 & Real estate & Real estate & Real estate & 0.66 & 0.66 & 0.66 \\
\hline W8 & Rangeland & Real estate & Real estate & 0.35 & 0.68 & 0.68 \\
\hline W9 & Real estate & Real estate & Real estate & 0.66 & 0.66 & 0.66 \\
\hline W10 & Real estate & Real estate & Real estate & 0.60 & 0.60 & 0.60 \\
\hline W11 & Rangeland & Rangeland & Rangeland & 0.50 & 0.50 & 0.50 \\
\hline W12 & Rangeland & Rangeland & Rangeland & 0.50 & 0.50 & 0.50 \\
\hline W13 & Rangeland & Rangeland & Real estate & 0.50 & 0.50 & 0.75 \\
\hline W14 & Rangeland & Rangeland & Real estate & 0.50 & 0.50 & 0.75 \\
\hline W15 & Rangeland & Real estate & Real estate & 0.40 & 0.70 & 0.70 \\
\hline W16 & Rangeland & Real estate & Real estate & 0.25 & 0.65 & 0.65 \\
\hline W17 & Real estate & Real estate & Real estate & 0.60 & 0.60 & 0.60 \\
\hline W18 & Rangeland & Rangeland & Real estate & 0.45 & 0.45 & 0.72 \\
\hline W19 & Rangeland & Real estate & Real estate & 0.40 & 0.70 & 0.70 \\
\hline W20 & Real estate & Real estate & Real estate & 0.70 & 0.70 & 0.70 \\
\hline W21 & Real estate & Real estate & Real estate & 0.60 & 0.60 & 0.60 \\
\hline W22 & Real estate & Real estate & Real estate & 0.60 & 0.60 & 0.60 \\
\hline
\end{tabular}

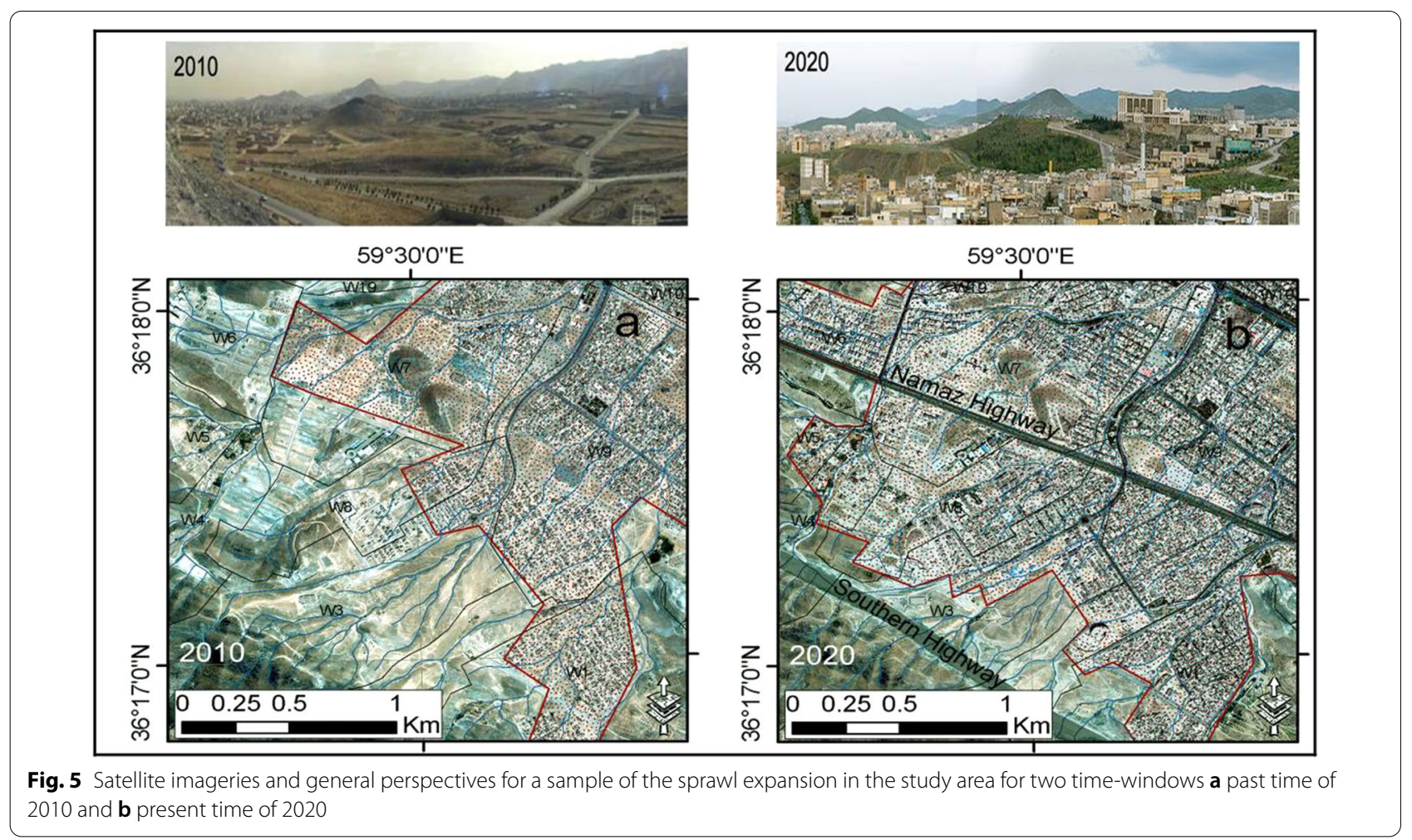




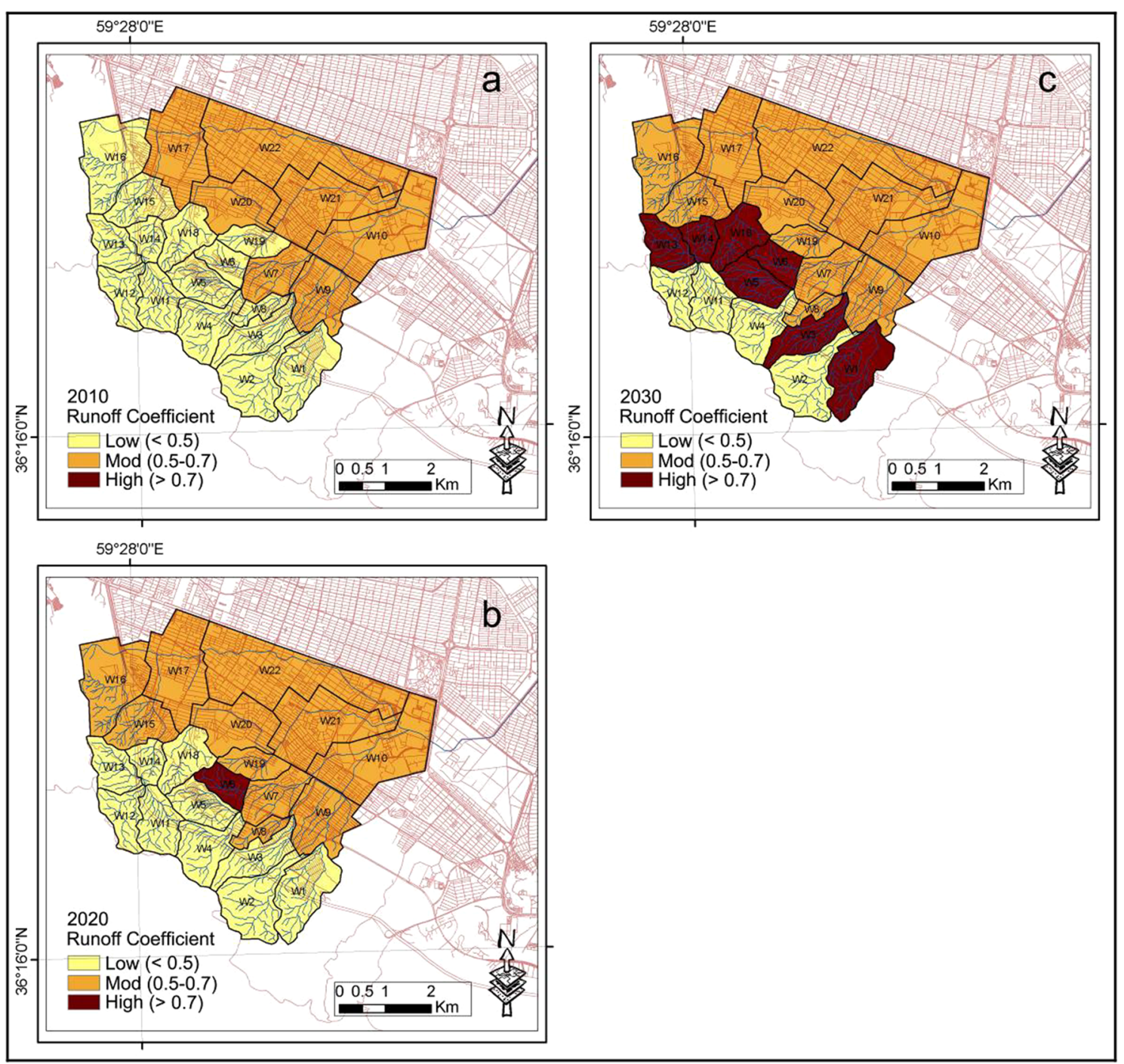

Fig. 6 Estimation runoff coefficients of each watershed in the study area for three time windows of a 2010, b 2020, and c 2030

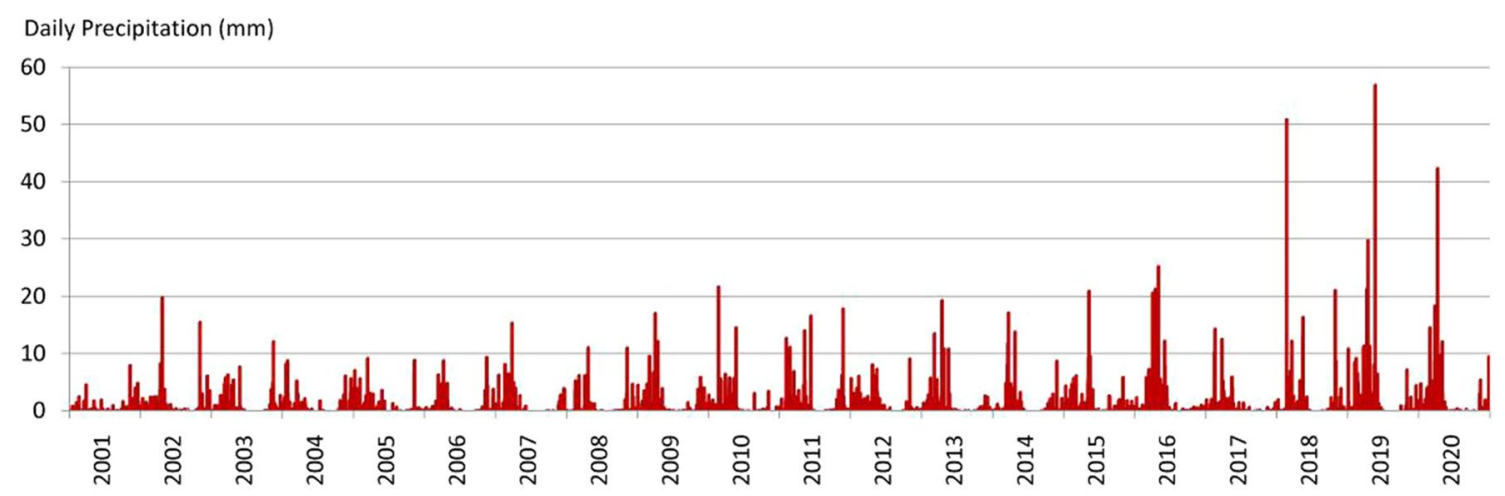

Fig. 7 Daily precipitation data in the study area within 2001-2020 


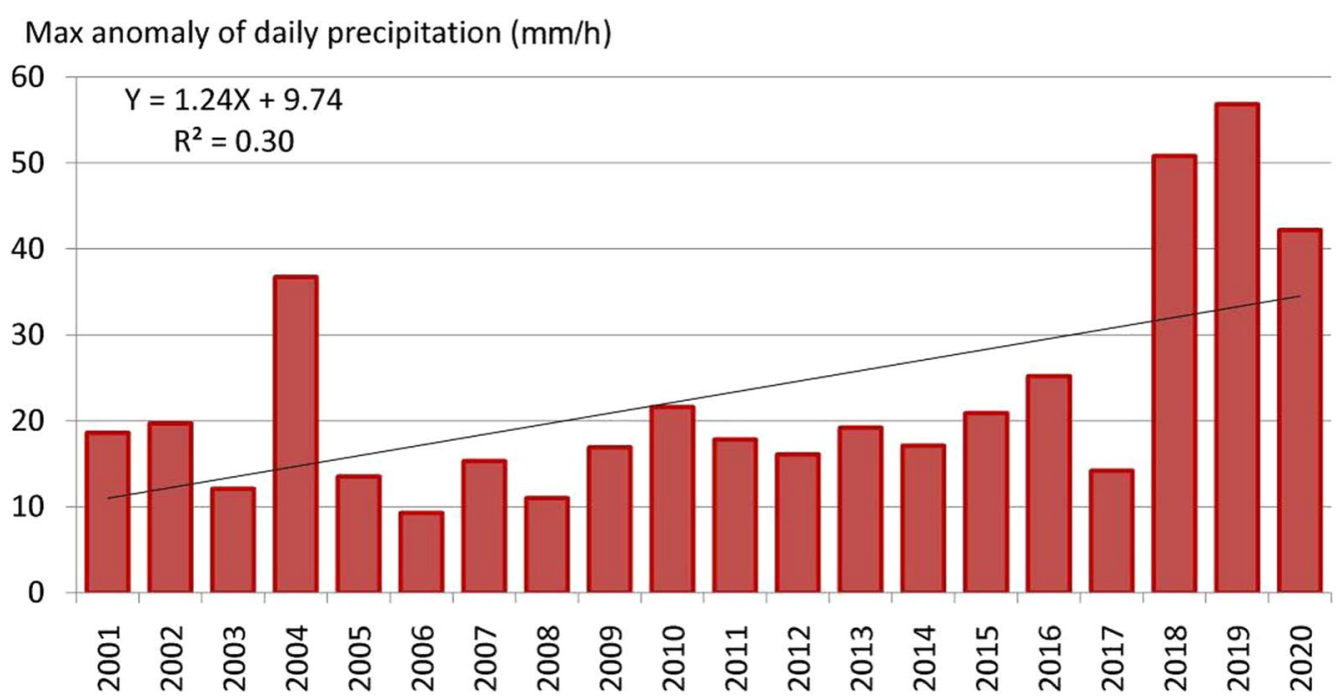

Fig. 8 Max anomaly of daily precipitation rates in the study area within 2001-2020

impacts, scholars revealed that global climate change had intensified the extreme precipitation events in recent years (Madsen et al. 2014; Westra et al. 2014; Berndtsson et al. 2019).

Table 4 Estimation of the maximum daily-precipitation rates and peak flood discharges in the watersheds within three periods of 2010, 2020, and 2030

\begin{tabular}{|c|c|c|c|c|c|c|}
\hline Watershed & $\begin{array}{l}2010 \text { precipitation } \\
\text { rate }(\mathrm{mm} / \mathrm{h})\end{array}$ & $\begin{array}{l}2020 \text { precipitation } \\
\text { rate }(\mathrm{mm} / \mathrm{h})\end{array}$ & $\begin{array}{l}2030 \text { precipitation } \\
\text { rate }(\mathrm{mm} / \mathrm{h})\end{array}$ & $\begin{array}{l}2010 \text { peak flood } \\
\text { discharge }\left(\mathrm{m}^{3} / \mathrm{s}\right)\end{array}$ & $\begin{array}{l}2020 \text { peak flood } \\
\text { discharge }\left(\mathrm{m}^{3} / \mathrm{s}\right)\end{array}$ & $\begin{array}{l}2030 \text { peak flood } \\
\text { discharge }\left(\mathrm{m}^{3} / \mathrm{s}\right)\end{array}$ \\
\hline W1 & 20 & 34 & 47 & 1.32 & 2.25 & 4.67 \\
\hline W2 & 20 & 34 & 47 & 1.36 & 2.32 & 3.21 \\
\hline W3 & 20 & 34 & 47 & 0.79 & 1.34 & 2.97 \\
\hline W4 & 20 & 34 & 47 & 1.03 & 1.75 & 2.42 \\
\hline W5 & 20 & 34 & 47 & 0.78 & 1.33 & 2.76 \\
\hline W6 & 20 & 34 & 47 & 0.52 & 1.31 & 1.82 \\
\hline W7 & 20 & 34 & 47 & 1.18 & 2.01 & 2.78 \\
\hline W8 & 20 & 34 & 47 & 0.24 & 0.80 & 1.11 \\
\hline W9 & 20 & 34 & 47 & 1.75 & 2.97 & 4.10 \\
\hline W10 & 20 & 34 & 47 & 2.88 & 4.89 & 6.76 \\
\hline W11 & 20 & 34 & 47 & 0.85 & 1.45 & 2.01 \\
\hline W12 & 20 & 34 & 47 & 0.71 & 1.21 & 1.67 \\
\hline W13 & 20 & 34 & 47 & 0.70 & 1.20 & 2.48 \\
\hline W14 & 20 & 34 & 47 & 0.45 & 0.77 & 1.60 \\
\hline W15 & 20 & 34 & 47 & 0.74 & 2.21 & 3.05 \\
\hline W16 & 20 & 34 & 47 & 0.87 & 3.84 & 5.31 \\
\hline W17 & 20 & 34 & 47 & 2.31 & 3.93 & 5.44 \\
\hline W18 & 20 & 34 & 47 & 0.76 & 1.29 & 2.86 \\
\hline W19 & 20 & 34 & 47 & 0.47 & 1.40 & 1.94 \\
\hline W20 & 20 & 34 & 47 & 1.91 & 3.25 & 4.49 \\
\hline W21 & 20 & 34 & 47 & 2.53 & 4.31 & 5.96 \\
\hline W22 & 20 & 34 & 47 & 4.10 & 6.97 & 9.64 \\
\hline
\end{tabular}




\section{Calculating peak flood discharges ( $Q p)$}

The estimation of Qp is shown in Table 4. The highest values of Qp in 2010, 2020, and 2030 were estimated equal to $4.102,6.973$, and $9.639 \mathrm{~m}^{3} / \mathrm{s}$ for the watershed W10. The watershed W10 is the ending outlet of all 22 watersheds, which is flowed across the zone of Ferdowsi University and is effluent in the main channel into the Malek-Abad Garden. The lowest values Qp in 2010, 2020, and 2030 were obtained equal to $<0.5,<1.0$, and $<1.5 \mathrm{~m}^{3} / \mathrm{s}$ for the watersheds W8 and W14, which have the lowest surface area in the upstream location of the study area. In the entire watersheds, the average flood peak discharges increased from 1.3 to $2.4 \mathrm{~m}^{3} / \mathrm{s}$ during the period from 2010 to 2020 and will increase up to $3.6 \mathrm{~m}^{3} / \mathrm{s}$ in 2030 .

\section{Estimation outlet cross-sections}

\section{Estimating time of concentration (Tc)}

Based on Equation 2, the Tc values were estimated for all watersheds, as shown in Table 5 . The largest Tc $(1.12 \mathrm{~h})$ belongs to the watershed W22 in downstream of the study area, which has the highest values of surface area $\left(44.3 \mathrm{~km}^{2}\right)$ and river length $(4.7 \mathrm{~km})$. Contrarily, the shortest Tc $(0.15 \mathrm{~h})$ belongs to watersheds W6, W14, and
W19 in the central part of the study area, which have the lowest river lengths $(<1.2 \mathrm{~km})$.

\section{Determining outlet cross-sections (Sc)}

Based on Equation 3, the outlet cross-sections were formulated to design flow ways and engineering control of the flood discharges downstream (Table 5). The broadest cross-section required for designing outlet channels was assumed for Watershed W10 with estimations of $17.56,32.01$, and $46.87 \mathrm{~m}^{2}$ in 2010, 2020, and 2030 .

It should be noted that the peak flood flows were estimated based on the outlet of each watershed downstream, not the upstream. However, the cumulative flood flows in the outlet of a watershed were considered based on the effluents of the upstream watersheds to determine the downstream outlet cross-sections. For instance, the effluent of the entire study area needs to design with concerning a cross-section of $46.87 \mathrm{~m}^{2}$ (e.g., with dimensions $3 \times 15 \mathrm{~m}$ ) in the future for accurate and invulnerable ejection of the cumulative flood discharges.

After the field observations, we controlled the most outlet cross-sections (Fig. 9) and found an insufficient

Table 5 Time of concentration, outlet cross-section, and flood susceptibility of the watersheds within three periods of 2010, 2020, and 2030

\begin{tabular}{|c|c|c|c|c|c|c|c|}
\hline Watershed & $\begin{array}{l}\text { Time of } \\
\text { concentration } \\
\text { (s) }\end{array}$ & $\begin{array}{l}2010 \text { outlet } \\
\text { cross section } \\
\left(\mathrm{m}^{2}\right)\end{array}$ & $\begin{array}{l}2020 \text { outlet } \\
\text { cross section } \\
\left(\mathrm{m}^{2}\right)\end{array}$ & $\begin{array}{l}2030 \text { outlet } \\
\text { cross section } \\
\left(\mathrm{m}^{2}\right)\end{array}$ & $\begin{array}{l}2010 \text { flood } \\
\text { susceptibility } \\
\left(\mathrm{m}^{3} / \mathrm{s}\right)\end{array}$ & $\begin{array}{l}2020 \text { flood } \\
\text { susceptibility } \\
\left(\mathrm{m}^{3} / \mathrm{s}\right)\end{array}$ & $\begin{array}{l}2030 \text { flood } \\
\text { susceptibility } \\
\left(\mathrm{m}^{3} / \mathrm{s}\right)\end{array}$ \\
\hline W1 & 971 & 0.54 & 0.91 & 1.89 & 1.32 & 2.25 & 4.67 \\
\hline W2 & 997 & 0.52 & 0.89 & 1.23 & 1.36 & 2.32 & 3.21 \\
\hline W3 & 934 & 0.29 & 0.50 & 1.11 & 0.79 & 1.34 & 2.97 \\
\hline W4 & 709 & 0.38 & 0.65 & 0.90 & 1.03 & 1.75 & 2.42 \\
\hline W5 & 743 & 0.36 & 0.62 & 1.28 & 0.78 & 1.33 & 2.76 \\
\hline W6 & 542 & 0.25 & 0.65 & 0.90 & 0.52 & 1.31 & 1.82 \\
\hline W7 & 883 & 1.70 & 3.10 & 4.72 & 2.88 & 5.27 & 8.01 \\
\hline W8 & 737 & 0.13 & 0.42 & 0.58 & 0.24 & 0.80 & 1.11 \\
\hline W9 & 963 & 2.60 & 4.63 & 7.45 & 4.06 & 7.22 & 11.60 \\
\hline W10 & 2302 & 17.56 & 32.01 & 46.87 & 22.11 & 40.31 & 59.04 \\
\hline W11 & 760 & 0.34 & 0.58 & 0.80 & 0.85 & 1.45 & 2.01 \\
\hline W12 & 792 & 0.30 & 0.50 & 0.69 & 0.71 & 1.21 & 1.67 \\
\hline W13 & 625 & 0.31 & 0.53 & 1.11 & 0.70 & 1.20 & 2.48 \\
\hline W14 & 542 & 1.17 & 2.00 & 3.39 & 2.38 & 4.05 & 6.88 \\
\hline W15 & 573 & 1.50 & 2.97 & 4.74 & 3.41 & 6.74 & 10.74 \\
\hline W16 & 1120 & 0.39 & 1.72 & 2.38 & 0.87 & 3.84 & 5.31 \\
\hline W17 & 1424 & 3.72 & 7.80 & 11.42 & 4.70 & 9.86 & 14.44 \\
\hline W18 & 832 & 0.37 & 0.63 & 1.40 & 0.76 & 1.29 & 2.86 \\
\hline W19 & 523 & 0.21 & 0.61 & 0.84 & 0.47 & 1.40 & 1.94 \\
\hline W20 & 1271 & 1.34 & 2.28 & 3.68 & 2.64 & 4.49 & 7.24 \\
\hline W21 & 2767 & 3.74 & 6.62 & 9.68 & 4.33 & 7.66 & 11.19 \\
\hline W22 & 4022 & 7.23 & 13.77 & 19.67 & 8.45 & 16.09 & 22.98 \\
\hline
\end{tabular}




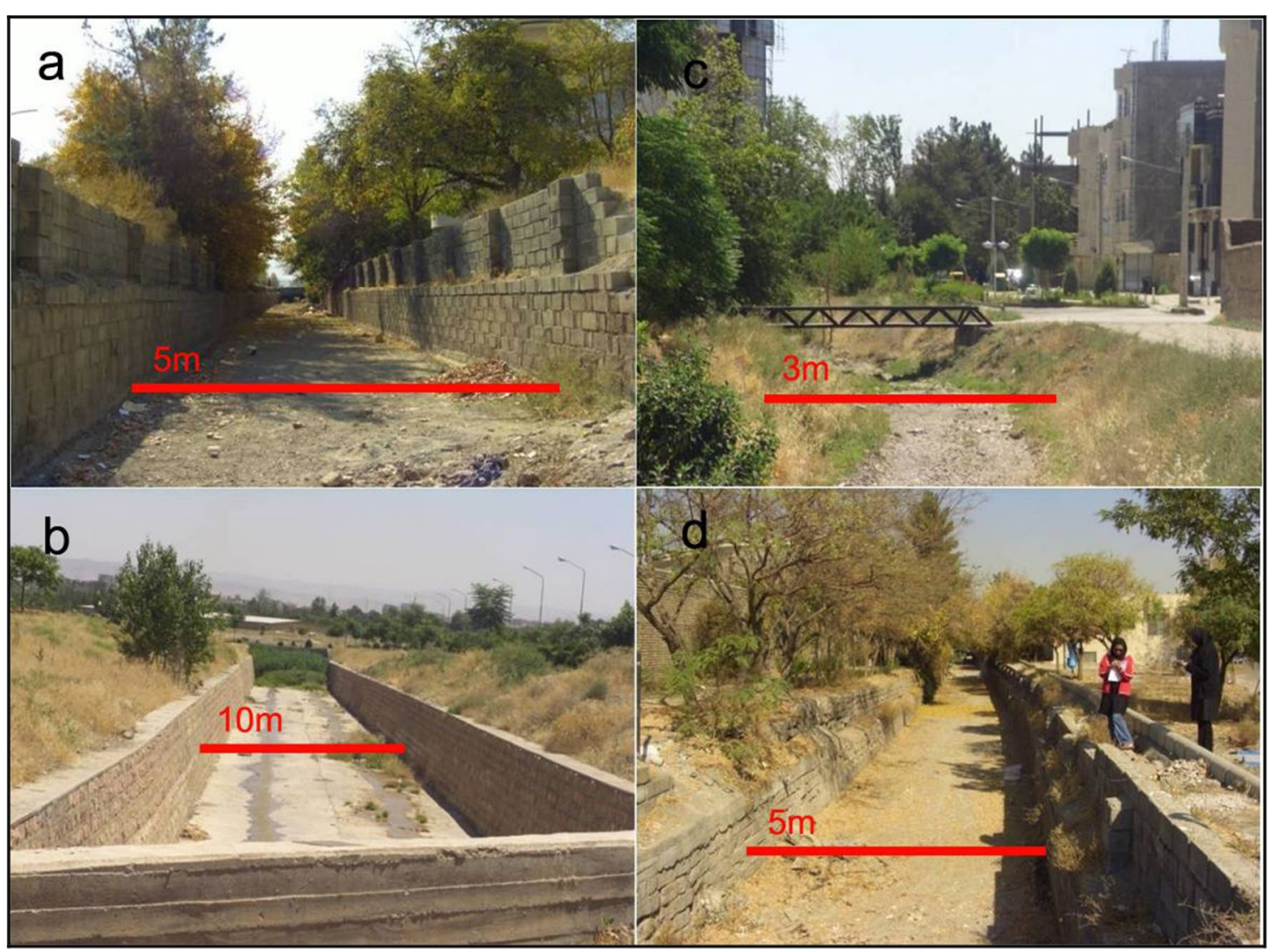

Fig. 9 The existing structure of outlet cross-sections in the field observation for some watersheds including a W9, b W10, c W20, and d W21

design for cross-sections regarding the present (2020) and the future (2030) flood effluents. For example, the outlet of watershed W10 with a width of $10 \mathrm{~m}$ and height of $2 \mathrm{~m}$ is not appropriate to eject the peak flood effluents.

\section{Flood susceptibility evaluation (FSE)}

FSE of the watersheds within three time-periods of 2010, 2020, and 2030 were defined as the cumulative flood discharges of each watershed after the concentration times considering the upstream watershed discharges and outlet cross-sections (Table 5). The highest FSE in 2010, 2020, and 2030, estimated equal to 22.11, 40.31, and $59.04 \mathrm{~m}^{3} / \mathrm{s}$ belongs to the watershed W10, similar to results Qp. Meanwhile, the lowest values of FSE in 2010, 2020, and 2030 were obtained equal to $<0.25$, $<0.65$, and $<0.85 \mathrm{~m}^{3} / \mathrm{s}$ for the watersheds W 8 and W14. The FSE map with three classes of low $\left(<3 \mathrm{~m}^{3} / \mathrm{s}\right)$, moderate $\left(3-10 \mathrm{~m}^{3} / \mathrm{s}\right)$, and high $\left(>10 \mathrm{~m}^{3} / \mathrm{s}\right)$ was produced in Fig. 10. We can observe only one watershed (W10) with a high value of FSE in 2010. However, the highest values of FSE included the watershed W22 and W10 in the present time (2020). The high class of FSE is predicted for
6 watersheds (W9, W10, W15, W17, W21, and W22) in 2030.

In the entire watersheds, the average FSE increased from 2.04 to $3.84 \mathrm{~m}^{3} / \mathrm{s}$ from 2010 to 2020 and will increase up to $5.76 \mathrm{~m}^{3} / \mathrm{s}$ in 2030 . In other words, the flood susceptibility will increase an average of 3.2 times in the future. Recent research indicated that the effects of the urbanized areas on flooding will increase approximately 2.7 times by the year 2030 (Güneralp et al. 2015; Park and Lee 2019). Hence, the research result in our study area revealed similar effects on the increasing flood susceptibility regarding the effects of the urban sprawl and climatic variations in the future. Globally, the previewed scenarios have demonstrated an increase in the frequency and magnitude of urban floods due to the changes in precipitation patterns and urban sprawl expansion (Zope et al. 2014; Yin et al. 2015; Park and Lee 2019).

\section{Model validation and implication}

Our results revealed that urbanization growth could result in higher impervious land areas, higher surface runoff coefficients, and higher peak flood discharges, 


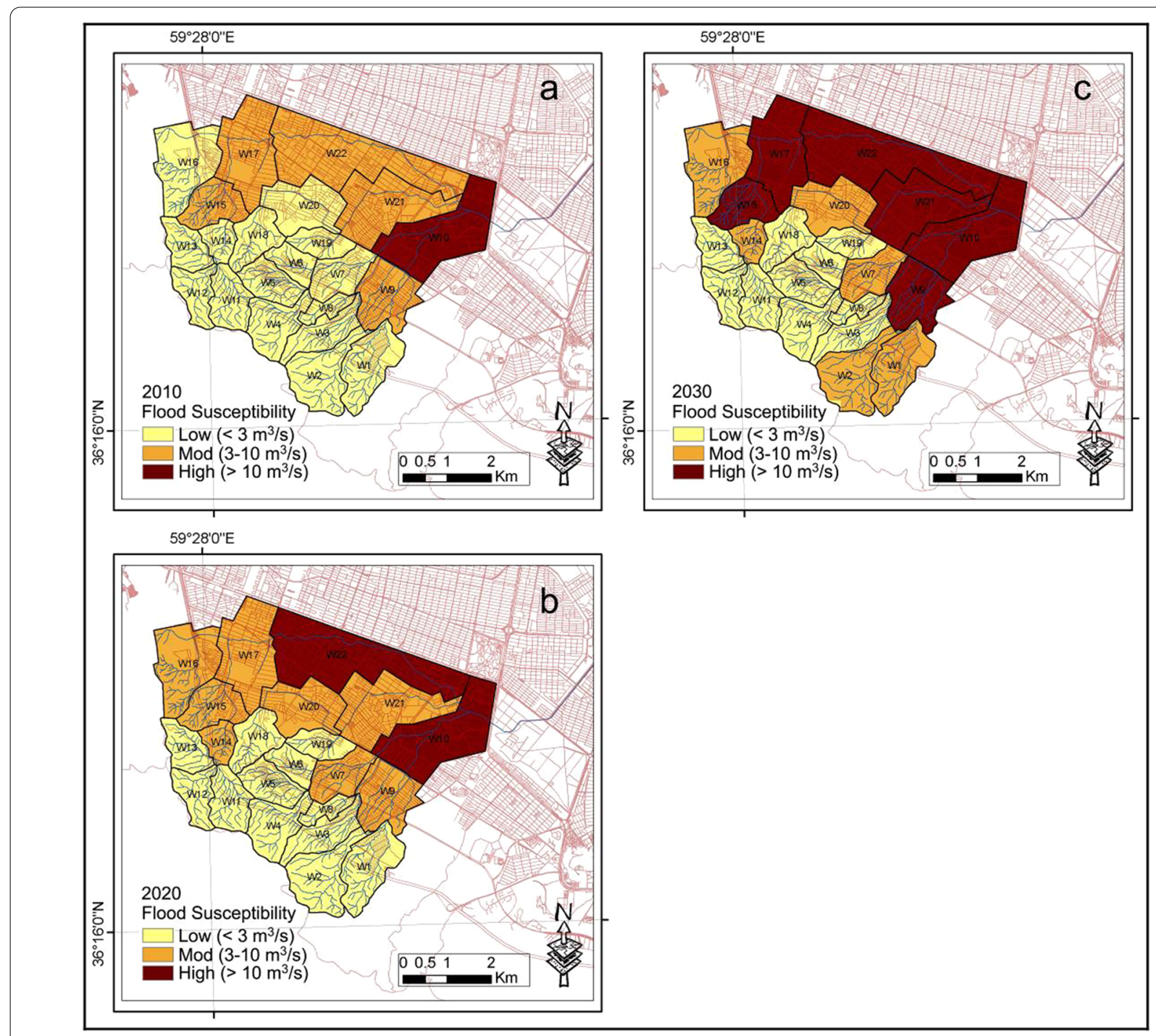

Fig. 10 Flood susceptibility evaluation of each watershed in the study area for three time windows of a 2010, b 2020, and c 2030

adopting Feng et al. (2021). In this regard, the FSE model could present the essential estimations to determine the flood hazard quantities (statistical dimension), the floodprone zones (spatial dimension), and the needs for future design (temporal dimension). We briefly concluded that the highest flood susceptibility $\left(>10 \mathrm{~m}^{3} / \mathrm{s}\right)$ would increase over six watersheds (46\% of the total study area) in the future. In this regard, we seriously pointed out that the prediction of the watersheds with high values of $\mathrm{Cr}$ should make aware the urban decision-makers about the critical effects of sprawl expansion on the increasing flood hazards in the pre-urban areas. In Fig. 11, the ROC curves for the model validity explained AUC values averagely over 0.8 for both periods of 2020 and 2030, exposing the very good performance of the model and excellent sensitivity. In detail, the ROC curve also revealed that the FSE model could be more sensitive in the prediction of future time.

The managerial implication of this research depends on prioritizing flood susceptible zones for land developers during the planning processes for urban and pre-urban regions. Urban planners, city officials, and policy-makers lacking appropriate hydrological understanding might implement equations and coefficients to create strategies against the risk of flooding in urban areas (Berndtsson et al. 2019). In this regard, the FSE model is constitutive of the current era of urbanization and must be linked to urban planning and management (Ahmad and Simonovic 2013; Su 2017). Meanwhile, the academic implication of the FSE model relates to the statistical and analytical 

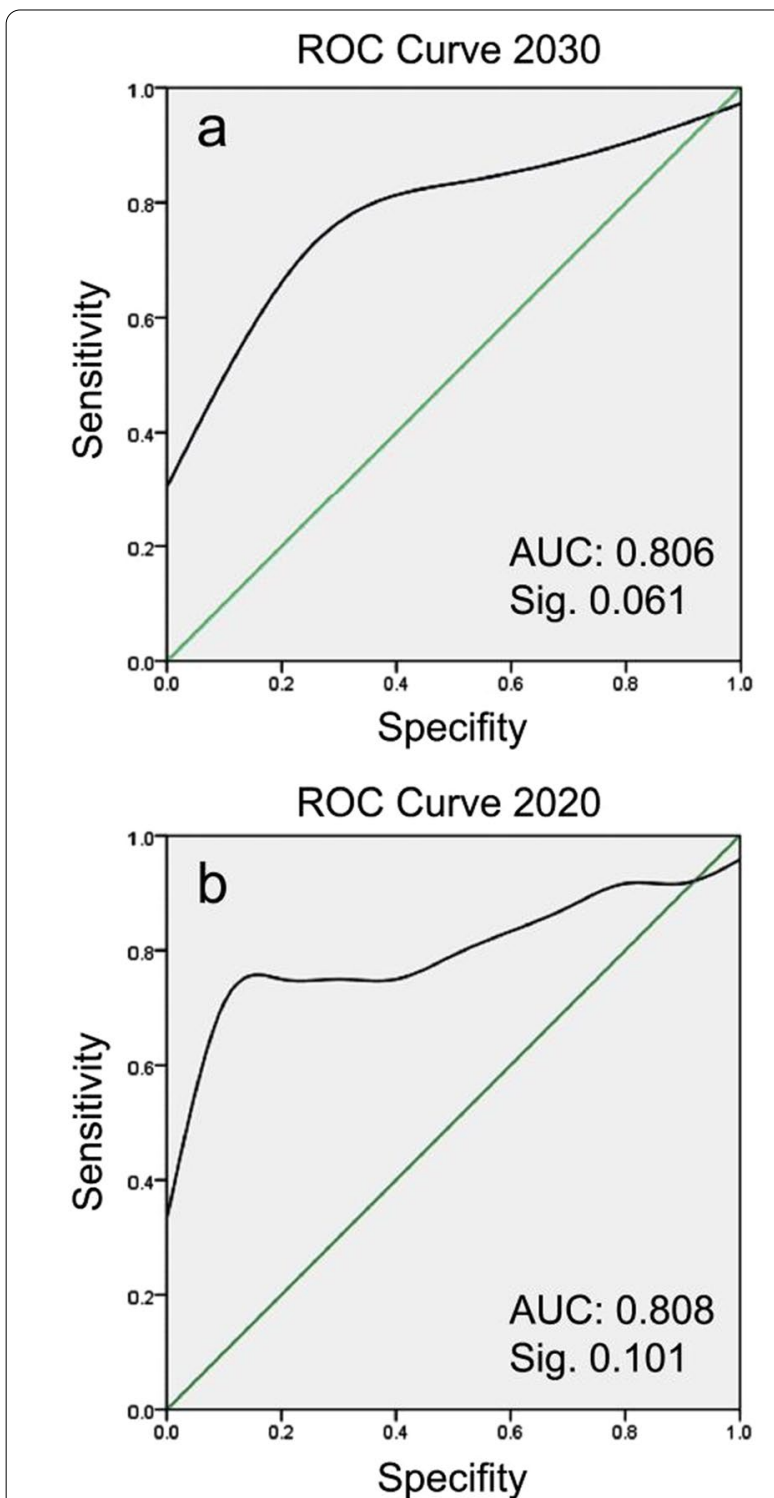

Fig. 11 ROC curve of the model for two time windows of a future time of 2030 and $\mathbf{b}$ quo status of 2020

procedures, which have the potential to supply dependent indicators concerning the runoff coefficient $(\mathrm{Cr})$ and time of concentration (Tc). The localized GIS-based works are proposed to determine the $\mathrm{Cr}$ and Tc values in the urban hydrological integrations. Besides, comparative research is recommended to detect the triggering role of climatic parameters and urban sprawl effect on flood susceptible zones.

\section{Conclusion}

The severe flooding of 2019 in Iran was a great momentum for the urban decision-makers and dwellers to consider the forthcoming urban flood hazards in the pre-urban and urban watersheds. In the present paper, we evaluated a flood susceptibility model in the southern watersheds of Mashhad city, in Iran, during three temporal windows of 2010, 2020, and 2030. As mentioned by NRIDR (2005), to integrate the GIS and RS for detection of flood susceptible prone zones in the national flood risk programs of Iran, we constructed an FSE model based on the utilization of RS and GIS tools to evaluate spatial and temporal levels of runoff variations, peak flood discharges, and flood hazard susceptibilities.

The spatial and statistical analysis revealed that about 16 watersheds (55\% of the total study area) have critical slope ranges over $15 \%$, and dominant soil units in 14 cases out of 22 watersheds ( $48 \%$ of the total study area) are observed as Mollisols, the most intensive soil units regarding erosion and weathering. Furthermore, the urban sprawl and real estate cover have influenced the study area by 7 watersheds ( $45 \%$ of total area) and 12 watersheds (65\% of total area) from 2010 to 2020 , and it is predicted for 18 watersheds $(>85 \%$ of total area) up to 2030 . Our results revealed the mean values of runoff coefficient $(\mathrm{Cr})$ from 0.50 (2010) to 0.65 (2030), where the highest values of $\mathrm{Cr}(>0.70)$ belonged to the watersheds with real estate cover, soil unit of Mollisols, and the slope ranges over 5-15\%. According to the precipitation data from 2001 to 2020 and its linear trend equation, the estimated maximum values of daily precipitation rate were assumed as 20,34 , and $47 \mathrm{~mm} / \mathrm{h}$ for time windows of 2010, 2020, and 2030, respectively. Consequently, the averagely cumulative flood discharges increased from 2.04 to $3.84 \mathrm{~m}^{3} / \mathrm{s}$ during the period from 2010 to 2020 and will increase up to $5.76 \mathrm{~m}^{3} / \mathrm{s}$ in 2030 . The flood susceptibility evaluation (FSE) will increase an average of 3.2 times in the future. Although the climatic variations in Iran exposed the increasing extreme events such as urban floods (Daneshvar et al. 2019a), the structure and design of urban areas can influence the intensity of local climate disasters (Ren 2015). In the study area, i.e., Mashhad city, Daneshvar et al. (2019b) have already noted the relationships between urban sprawl and local climatic factors. Similarly, our findings revealed both effects of climatic anomalies and sprawl expansions on the intensity of flood disaster and susceptibility in the study area.

\section{Acknowledgements}

We thank anonymous reviewers for technical suggestions on data interpretations. 


\section{Authors' contributions}

All authors were equally involved in analyzing and editing the paper. All authors read and approved the final manuscript.

\section{Funding}

This study was not funded by any Grant.

\section{Availability of data and materials}

The data that support the findings of this study are available from the corresponding author upon request.

\section{Declarations}

\section{Ethics approval and consent to participate}

This article does not contain any studies with participants performed by any of the authors.

\section{Consent for publication}

Not applicable.

\section{Competing interests}

The authors declare that they have no competing interests.

\section{Author details}

'Department of Geography and Urban Planning, Research Institute of Shakhes Pajouh, Isfahan, Iran. ${ }^{2}$ Head of Departments and Chancellor, Research Institute of Shakhes Pajouh, Isfahan, Iran. ${ }^{3}$ Department of Geography and Natural Hazards, Research Institute of Shakhes Pajouh, Isfahan, Iran.

Received: 11 September 2021 Accepted: 3 December 2021

Published online: 13 December 2021

\section{References}

Abass K, Buor D, Afriyie K, Dumedah G, Segbefi AY, Guodaar L, Garsonu EK, Adu-Gyamfi S, Forkuor D, Ofosu A, Mohammed A, Gyasi RM (2020) Urban sprawl and green space depletion: implications for flood incidence in Kumasi, Ghana. Int J Disaster Risk Reduct 51:101915

Ahmad S, Simonovic SP (2013) Spatial and temporal analysis of urban flood risk assessment. Urban Water J 10(1):26-49

Ahmad T, Pandey AC, Kumar A (2017) Evaluation of flood impacts vis-à-vis urban sprawl and changing climate in Srinagar city and its environs. J Clim Change Water 4:39-47

Ahmadi B, Moradkhani H (2019) Revisiting hydrological drought propagation and recovery considering water quantity and quality. Hydrol Proc 33:1492-1505

Al-Ghamdi KA, Elzahrany RA, Mirza MN, Dawod GM (2012) Impacts of urban growth on flood hazards in Makkah city, Saudi Arabia. Int J Water Res Environ Eng 4(2):23-34

Baiamonte $\mathrm{G}$ (2020) A rational runoff coefficient for a revisited rational formula. Hydrol Sci J 65(1):112-126

Berndtsson R, Becker P, Persson A, Aspegren H, Haghighatafshar S, Jönsson K, Larsson R, Mobini S, Mottaghi M, Nilsson J, Nordström J, Pilesjö P, Scholz M, Sternudd C, Sörensen J, Tussupova K (2019) Drivers of changing urban flood risk: a framework for action. J Environ Manag 240:47-56

Bhadra A, Panigrahy N, Singh R, Raghuwanshi NS, Mal BC, Tripathi MP (2008) Development of a geomorphological instantaneous unit hydrograph model for scantily gauged watersheds. J Environ Model Softw 23:1013-1025

Cheah R, Billa L, Chan A, Teo FY, Pradhan B, Alamri AM (2019) Geospatial modelling of watershed peak flood discharge in Selangor, Malaysia. Water $11: 2490$

Daneshvar MRM, Ebrahimi M, Nejadsoleymani H (2019a) An overview of climate change in Iran: facts and statistics. Environ Syst Res 8:7

Daneshvar MRM, Rabbani G, Shirvani S (2019b) Assessment of urban sprawl effects on regional climate change using a hybrid model of factor analysis and analytical network process in the Mashhad city, Iran. Environ Syst Res 8:23
Dastorani MT, Talebi A, Dastorani M (2010) Using neural networks to predict run off from ungauged catchments. Asian J Appl Sci 3(6):399-410

Dawson RJ, Ball T, Werritty J, Werritty A, Hall JW, Roche N (2011) Assessing the effectiveness of non-structural flood management measures in the Thames Estuary under conditions of socio-economic and environmental change. Glob Environ Chang 21:628-646

Del Giudice G, Padulano R, Rasulo G (2014) Spatial prediction of the runoff coefficient in Southern Peninsular Italy for the index flood estimation. Hydrol Res 45(2):263-281

Devi NN, Sridharan B, Kuiry SN (2019) Impact of urban sprawl on future flooding in Chennai city, India. J Hydrol 574:486-496

Du J, Qian L, Rui H, Zuo T, Zheng D, Xu Y, Xu C (2012) Assessing the effects of urbanization on annual runoff and flood events using an integrated hydrological modeling system for Qinhuai River Basin, China. J Hydrol 464-465:127-139

Ebrahimi M, Nejadsoleymani H, Sadeghi A, Daneshvar MRM (2021) Assessment of the soil loss-prone zones using the USLE model in northeastern Iran. Paddy Water Environ 19:71-86

Feng B, Zhang Y, Bourke R (2021) Urbanization impacts on flood risks based on urban growth data and coupled flood models. Nat Hazards 106:613-627

Fletcher T, Andrieu H, Hamel P (2013) Understanding, management and modelling of urban hydrology and its consequences for receiving waters: a state of the art. Adv Water Res 51:261-279

Güneralp B, Güneralp I, Liu Y (2015) Changing global patterns of urban exposure to flood and drought hazards. Glob Environ Chang 31:217-225

Hayes DC, Young RL (2006). Comparison of peak discharge and runoff characteristic estimates from the rational method to field observations for small basins in central Virginia. Scientific report 2005-5254, US. Geological survey, Reston, Virginia. https://pubs.usgs.gov/sir/2005/5254

Hengl T, de Jesus JM, MacMillan RA, Batjes NH, Heuvelink GB, Ribeiro E, Samuel-Rosa A, Kempen B, Leenaars JGB, Walsh MG, Gonzalez MR, BondLamberty B (2014) SoilGrids $1 \mathrm{~km}$ — global soil information based on automated mapping. PLOS One 9(8):e105992

Hengl T, de Jesus JM, Heuvelink GBM, Ruiperez Gonzalez M, Kilibarda M, Blagotíc A, Shangguan W, Wright MN, Geng X, Bauer-Marschallinger B, Guevara MA, Vargas R, MacMillan RA, Batjes NH, Leenaars JGB, Ribeiro E, Wheeler I, Mantel S, Kempen B (2017) SoilGrids250m: global gridded soil information based on Machine Learning. PLOS ONE 12(2):e0169748

Hoseini Y, Azari A, Pilpayeh A (2017) Flood modeling using WMS model for determining peak flood discharge in southwest Iran case study: Simili basin in Khuzestan Province. Appl Water Sci 7:3355-3363

Huang L, He B, Han L, Liu J, Wang H, Chen Z (2017) A global examination of the response of ecosystem water use efficiency to drought based on MODIS data. Sci Total Environ 601-602:1097-1107

Hung CLJ, James LA, Carbone GJ (2018) Impacts of urbanization on storm flow magnitudes in small catchments in the Sand hills of South Carolina, USA. Anthropocene 23:17-28

Huong HTL, Pathirana A (2013) Urbanization and climate change impacts on future urban flooding in Can Tho city Vietnam. Hydrol Earth Syst Sci 17(1):379-394

Isidoro JM, de Lima JL, Leandro J (2012) Influence of wind-driven rain on the rainfall-runoff process for urban areas: scale model of high-rise buildings. Urban Water J 9(3):199-210

Kirpich ZP (1940) Time of concentration of small agricultural watersheds. Civ Eng 10(6):362

Kulkarni AT, Bodke SS, Rao EP, Eldho TI (2014) Hydrologic impact on change in land use/land cover in an urbanizing catchment of Mumbai: a case study. J Hydraul Eng 20:314-323

Li GF, Xiang XY, Tong YY, Wang HM (2013) Impact assessment of urbanization on flood risk in the Yangtze River Delta. Stoch Env Res Risk A 27(7):1683-1693

Li X, Chen G, Liu X, Liang X, Wang S, Chen Y, Pei F, Xu X (2017) A new global land-use and land-cover change product at a 1-km resolution for 2010 to 2100 based on human-environment interactions. Ann Am Assoc Geogr 107(5):1040-1059

Liuzzo L, Sammartano V, Freni G (2019) Comparison between different distributed methods for flood susceptibility mapping. Water Resour Manag 33(9):3155-3173 
Madsen H, Lawrence D, Lang M, Martinkova M, Kjeldsen TR (2014) Review of trend analysis and climate change projections of extreme precipitation and floods in Europe. J Hydrol 519:3634-3650

Mahmoudzadeh A, Daneshvar MRM (2019) A brief overview of the natural hazards caused by the precipitation in March 2019, report No. C-2019-04. Shakhes Pajouh Research Institute, Tehran

Mihu-Pintilie A, Cîmpianu Cl, Stoleriu CC, Pérez MN, Paveluc LE (2019) Using high-density lidar data and $2 \mathrm{~d}$ stream flow hydraulic modeling to improve urban flood hazard maps: a HEC-RAS multi-scenario approach. Water 11:1832

Miller JD, Hutchins M (2017) The impacts of urbanisation and climate change on urban flooding and urban water quality: a review of the evidence concerning the United Kingdom. J Hydrol Reg Stud 12:345-362

Mousavi SM, Roostaei S, Rostamzadeh H (2019) Estimation of flood land use/land cover mapping by regional modelling of flood hazard at sub-basin level case study: Marand basin. Geomatics Nat Hazards Risk 10(1):1155-1175

NRIDR (2005) National report of the Islamic Republic of Iran on disaster reduction. World Conference on Disaster Reduction. Kobe, Hyogo, Japan. https://www.unisdr.org/2005/mdgs-drr/national-reports/Iran-report.pdf

Ntelekos AA, Oppenheimer M, Smith JA, Miller AJ (2010) Urbanization, climate change and flood policy in the United States. Clim Change 103(3-4):597-616

Parak M, Pegram GG (2006) The rational formula from the runhydrograph. Water SA 32(2):163-180

Park K, Lee MH (2019) The development and application of the urban flood risk assessment model for reflecting upon urban planning elements. Water 11:920

Park S, Jeon S, Kim S, Choi C (2011) Prediction and comparison of urban growth by land suitability index mapping using GIS and RS in South Korea. Landsc Urban Plan 99:104-114

Petras V, Du Plessis PH (1987) Catalogue of hydrological parameters. Flood studies, report No. 6. Department of Water Affairs, Pretoria

Pirnia A, Darabi H, Choubin B, Omidvar E, Onyutha C, Haghighi AT (2019) Contribution of climatic variability and human activities to stream flow changes in the Haraz River basin, northern Iran. J Hydro-Environ Res 25:12-24

Prosdocimi I, Kjeldsen TR, Miller JD (2015) Detection and attribution of urbanization effect on flood extremes using nonstationary flood-frequency models. Water Resour Res 51:4244-4262

Rabbani G, Madanian S, Daneshvar MRM (2021) Multi-criteria modeling for land suitability evaluation of the urban greenbelts in Iran. Model Earth Syst Environ 7:1291-1307

Rahman M, Ningsheng C, Mahmud Gl, Islam MM, Pourghasemi HR, Ahmad H, Habumugisha JM, Washakh RMA, Alam M, Liu E, Han Z, Ni H, Shufeng T, Dewan A (2021) Flooding and its relationship with land cover change, population growth, and road density. Geosci Front 12:101224

Rahmati O, Darabi H, Haghighi AT, Stefanidis S, Kornejady A, Nalivan OA, Bui DT (2019) Urban flood hazard modeling using self-organizing map neural network. Water 11:2370

Ren G (2015) Urbanization as a major driver of urban climate change. Adv Clim Change Res 6:1-6

Scionti F, Miguez MG, Barbaro G, De Sousa MM, Foti G, Canale C (2018) Integrated methodology for urban flood risk mitigation in Cittanova, Italy. J Water Resour Plan Manag 144(10):05018013

Shah MAR, Renaud FG, Anderson CC, Wild A, Domeneghetti A, Polderman A, Votsis A, Pulvirenti B, Basu B, Thomson C, Panga D, Pouta E, Toth E, Pilla F, Sahani J, Ommer J, Zohbi JE, Munro K, Stefanopoulou M, Loupis M, Pangas N, Kumar P, Debele S, Preuschmann S, Panga D (2020) A review of hydro-meteorological hazard, vulnerability, and risk assessment frameworks and indicators in the context of nature-based solutions. Int J Disaster Risk Reduct 50:101728

Shanableh A, Al-Ruzouq R, Yilmaz AG, Siddique M, Merabtene T, Imteaz MA (2018) Effects of land cover change on urban floods and rainwater harvesting: a case study in Sharjah. UAE Water 10:631

Su W (2017) Measuring the past 20 years of urban-rural land growth in floodprone areas in the developed Taihu Lake watershed, China. Front Earth Sci 11:361-371

Suharyanto A, Devia YP, Wijatmiko I (2021) Floodway design affected by land use changes in an urbanized area. J Water Land Dev 49:259-266
Thompson DB (2006) The rational method, regional regression equations, and site-specific flood-frequency relations. Research Report 4405-1, Texas Tech University. https://ttu-ir.tdl.org/handle/2346/22794. Accessed 1 May 2020

Tierolf L, De Model H, Van Vliet J (2021) Modeling urban development and its exposure to river flood risk in Southeast Asia. Comput Environ Urban Syst 87:101620

Tingsanchali T (2012) Urban Flood Disaster Management. Procedia Eng $32: 25-37$

UNCTI (2019) Post disaster needs assessment (PDNA): Iran 2019 floods. Archived by the United Nations Country Team in Iran. https://reliefweb. int/report/iran-islamic-republic/post-disaster-needs-assessment-pdnairan-2019-floods-lorestan-khuzestan. Accessed 1 May 2020

Wagner PD, Bhallamudi SM, Narasimhan B, Kantakumar LN, Sudheer KP, Kumar S, Schneider K, Fiener P (2016) Dynamic integration of land use changes in a hydrologic assessment of a rapidly developing Indian catchment. Sci Total Environ 539:153-164

Wang P, Huang C, de Colstoun ECB, Tilton JC, Tan B (2017) Documentation for the global human built-up and settlement extent (HBASE) dataset from Landsat. NASA Socioeconomic Data and Applications Center, Palisades. https://doi.org/10.7927/H48W3BCM

Westra S, Fowler HJ, Evans JP, Alexander LV, Berg P, Johnson F, Kendon EJ, Lenderink G, Roberts NM (2014) Future changes to the intensity and frequency of short-duration extreme rainfall. Rev Geophys 52:522-555

Yazd NK, Yazd NK, Daneshvar MRM (2019) Strategic spatial analysis of urban greenbelt plans in Mashhad city. Iran Environ Syst Res 8:30

Yesilnacar E, Topal T (2005) Landslide susceptibility mapping: a comparison of logistic regression and neural networks methods in a medium scale study, Hendek region (Turkey). Eng Geol 79(3-4):251-266

Yin J, Ye M, Yin Z, Xu S (2015) A review of advances in urban flood risk analysis over China. Stoch Environ Res Risk Assess 29:1063-1070

Zeinali V, Vafakhah M, Sadeghi SH (2019) Impact of urbanization on temporal distribution pattern of storm runoff coefficient. Environ Monit Assess 191:595

Zhao G, Xu Z, Pang B, Tu T, Xu L, Du L (2019) An enhanced inundation method for urban flood hazard mapping at the large catchment scale. J Hydrol 571:873-882

Zope PE, Eldho TI, Jothiprakash V (2014) Impacts of urbanization on flooding of a coastal urban catchment: a case study of Mumbai city, India. Nat Hazards 75:887-908

Zope PE, Eldho TI, Jothiprakash V (2016) Impacts of land use-land cover change and urbanization on flooding: a case study of Oshiwara River Basin in Mumbai, India. CATENA 145:142-154

\section{Publisher's Note}

Springer Nature remains neutral with regard to jurisdictional claims in published maps and institutional affiliations.

\section{Submit your manuscript to a SpringerOpen ${ }^{\circ}$ journal and benefit from:}

- Convenient online submission

- Rigorous peer review

- Open access: articles freely available online

- High visibility within the field

- Retaining the copyright to your article

Submit your next manuscript at $\boldsymbol{\nabla}$ springeropen.com 